\section{ragnew SUMBER DAYA MANUSIA}

Irfandi Buamonabot, lahir di Galela, Kabupaten Halmahera Utara 35 tahun lalu. Menyelesaikan S1 di Program Studi Manajemen Universitas Khairun pada tahun 2004, kemudian melanjutkan studi S2 pada Program Magister Sains, Fakultas Ekonomika dan Bisnis Universitas Gadjah Mada tahun 2012.

Menjadi dosen tetap pada Politeknik Sains \& Teknologi Wiratama Maluku Utara pada bulan Mei 2012-September 2020. Selanjutnya bulan Oktober 2020 sampai sekarang menjadi dosen tetap di Program Studi Manajemen, Fakultas Ekonomi dan Bisnis Universitas Khairun. Selain itu, yang bersangkutan juga menjadi dosen tidak tetap di Universitas Muhammadiyah Maluku Utara, Institut Agama Islam Negeri Ternate dan UPBJJ-UT Ternate.

Penulis sekarang aktif mengikuti konferensi nasional dan Internasional dan juga publikasi seperti Indonesia Finance Association (IFA) International Conference 5th di Manado tahun 2019, FANRes International Conference di Ternate tahun 5th 2019 di Ternate, International Conference on Accounting, Management, and Economics 4th 2019 di Makassar, International Conference of Project Management 2019 dan Seminar Nasional dan Gelar Hasil Pengabdian Masyarakat Universitas Terbuka tahun 2019 di Tangerang. International Conference on Accounting, Management, and Economics 5th 2020 di Makassar, Gadjah Mada International Conference on Economics 8th and Business dan Gadjah Mada International Conference on Islamic 5th 2020 di Yogyakarta (virtual), Seminar Nasional dan call for paper Universitas Islam Syekh Yusuf 2020 di Tangerang, International Conference of Project Management di Malang 2020 (virtual), International Conference of Project Management 11th 2021 di Malang, International Conference on Management in Emerging Markets 6th 2021 di Bandung (virtual) dan International Conference on Information Communication and Management 11th di Tokyo, Jepang tahun 2021 (virtual), sedangkan untuk publikasi yang sudah dilakukan pada jurnal nasional sinta 2 yakni Journal of Asian Finance, Economics and Business, Binus Business Review dan Society. Seluruh kegiatan ini dibiayai oleh Universitas Khairun.
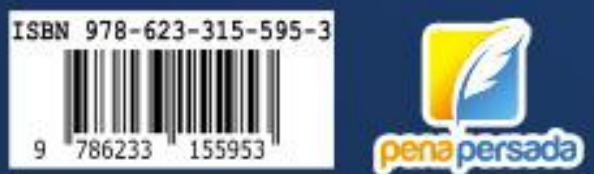

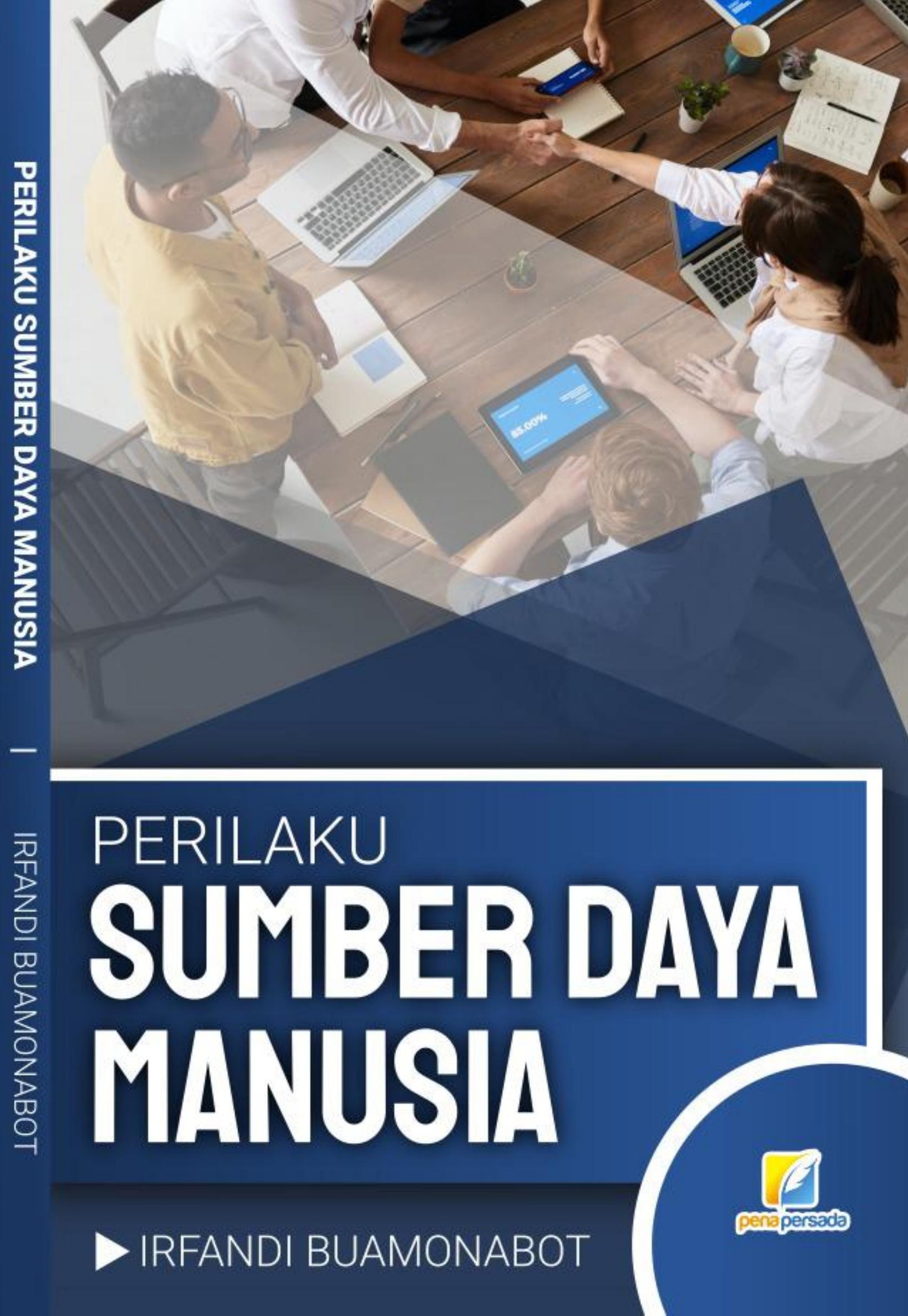




\title{
PERILAKU SUMBER DAYA MANUSIA
}

\author{
IRFANDI BUAMONABOT
}

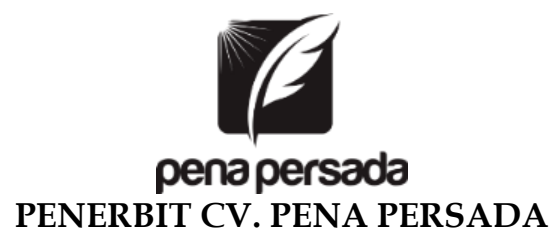




\title{
PERILAKU SUMBER DAYA MANUSIA
}

\author{
Penulis: \\ Irfandi Buamonabot \\ ISBN : 978-623-315-595-3 \\ Editor: \\ Rusfik Yulli Anur Wati \\ Design Cover : \\ Retnani Nur Briliant \\ Layout : \\ Hasnah Aulia

\section{Penerbit CV. Pena Persada} \\ Redaksi : \\ Jl. Gerilya No. 292 Purwokerto Selatan, Kab. Banyumas \\ Jawa Tengah \\ Email : penerbit.penapersada@gmail.com \\ Website : penapersada.com Phone : (0281) 7771388 \\ Anggota IKAPI \\ All right reserved \\ Cetakan pertama : 2021
}

Hak Cipta dilindungi oleh undang-undang. Dilarang memperbanyak karya tulis ini dalam bentuk apapun tanpa izin penerbit 


\section{KATA PENGANTAR}

Segala puji senantiasa kita panjatkan kehadirat Allah Swt, atas segala rahmat dan karunianya, akhirnya penulis dapat menyelesaikan penyusunan buku yang berjudul "Perilaku Sumber Daya Manusia “. Saya menyadari bahwa tanpa bantuan dan bimbingan dari berbagai pihak sangatlah sulit bagi saya untuk menyelesaikan karya ini. Oleh karena itu, saya mengucapkan banyak terima kasih pada semua pihak yang telah membantu penyusunan buku ini. Sehingga buku ini bisa hadir di hadapan pembaca.

Dalam buku ini membahas tentang pengaruh stres peran pada kepuasan kerja, dan implikasinya pada intensi keluar dengan variabel afek positif sebagai pemoderasi. Stres kerja merupakan kondisi yang muncul akibat adanya ketidaksesuaian antara individu dengan pekerjaannya. Ketidaksesuaian tersebut berdampak pada perubahan dan penyimpangan fungsi normal individu tersebut. Ketika seseorang karyawan mengalami penurunan kepuasan kerja maka akan meningkatkan tingginya intensi keluar sebagai karyawan dalam sebuah perusahaan/instansi terkait.

Penulis menyadari bahwa buku ini masih jauh dari kesempurnaan. Oleh karena itu kritik dan saran yang membangun sangat dibutuhkan guna penyempurnaan buku ini. Akhir kata saya berharap Allah Swt berkenan membalas segala kebaikan semua pihak yang telah membantu

Penulis 


\section{DAFTAR ISI}

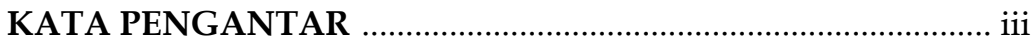

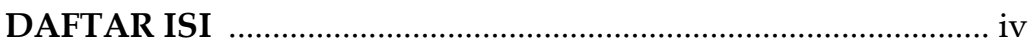

BAB I PENDAHULUAN …………………………..................... 1

BAB II STRES KERJA

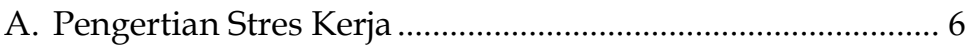

B. Faktor-faktor Penyebab Stres Kerja...................................... 7

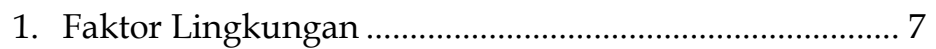

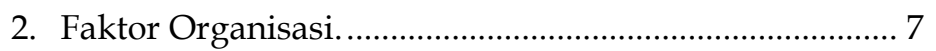

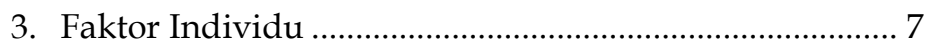

C. Dampak Stres Kerja pada Perusahaan................................... 8

D. Dampak Stres Kerja pada Karyawan ...................................... 8

BAB IIIKONFLIK DAN AMBIGUITAS PERAN

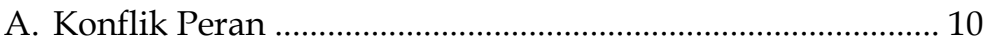

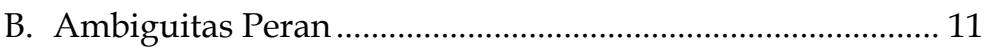

BAB IV KEPUASAN KERJA

A. Akibat Kepuasan Kerja .......................................................... 13

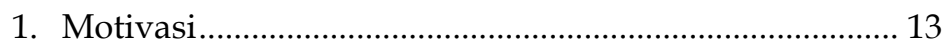

2. Perilaku Kewarganegaraan Organisasional (Organizational Citizenship Behavior) ............................. 14

3. Ketidakhadiran (absenteeism) .......................................... 14

4. Pemikiran untuk meninggalkan perusahaan

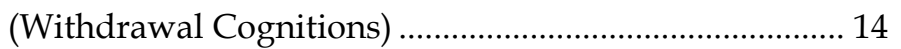

5. Prestasi Kerja (Job Performance)........................................ 15

B. Faktor-faktor yang Memengaruhi Kepuasan Kerja .............. 15

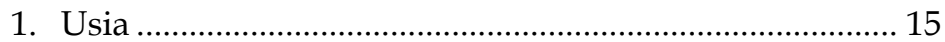

2. Keanggotaan Serikat Pekerja ............................................. 16

3. Besar Kecil Tempat Kerja ................................................... 16

4. Tingkat pendidikan ......................................................... 16

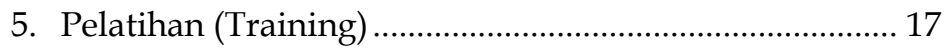

6. Status Perkawinan …………........................................... 17

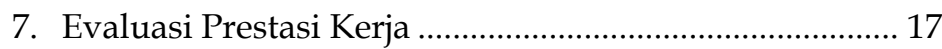

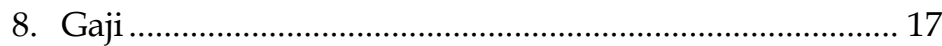

9. Politik Organisasional (Organisasional Politics) ............ 18 


\section{BAB V INTENSI KELUAR DAN AFEK POSITIF}

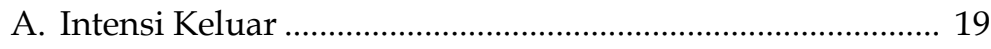

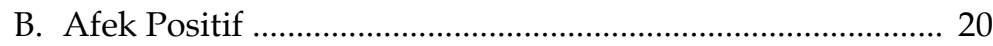

BAB VIFAKTOR PENENTU DALAM MENINGKATKAN KEPUASAN KERJA

A. Pengaruh Konflik Peran pada Kepuasan Kerja ................... 22

B. Pengaruh Ambiguitas Peran pada Kepuasan Kerja............. 23

C. Pengaruh Kepuasan Kerja pada Intensi Keluar................... 25

D. Pengaruh Pemoderasian Afek Positif pada Hubungan

Kepuasan Kerja dan Intensi Keluar...................................... 27

BAB VII PENUTUP ……………………………….................... 30

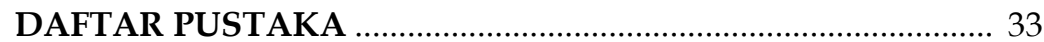


PERILAKU SUMBER DAYA MANUSIA 


\section{BAB I \\ PENDAHULUAN}

Telah lama diakui bahwa stres peran (role stress) adalah kualitas penting penentu kehidupan, sebagaimana dikemukakan oleh Seyle (dalam Kemery, Mossholder, dan Bedeian, 1987). Sebagian besar dari kita menyadari bahwa stres karyawan merupakan masalah yang semakin banyak kita jumpai dalam organisasi. Artinya, karyawan yang bekerja lebih lama dari waktu normal kerja mengalami stres yang lebih tinggi sehingga mengakibatkan kinerja perusahaan menurun (Slobogin, 2001).

Stres karyawan yang bekerja di perusahaan tentu berbeda dengan orang yang tidak memiliki pekerjaan. Karyawan yang bekerja tentunya memiliki stres yang lebih tinggi dibandingkan dengan orang yang tidak memiliki pekerjaan. Stres di tempat kerja berhubungan dengan pekerjaan dari karyawan itu sendiri, sedangkan stres di rumah seperti ibu rumah tangga yang frustasi tidak boleh bekerja lagi padahal berpendidikan tinggi. Dengan melonjaknya jumlah pasangan bekerja di akhir abad 20, perbedaan antara stres orang yang bekerja dan tidak bekerja semakin tidak jelas (Ivanchevich, Konopaske dan Matteson, 2008).

Menurut Van Sell, Brief dan Schuler (dalam Schuler, 1982), dua kualitas peran dalam organisasi yang telah banyak diteliti adalah konflik peran dan ambiguitas peran. Kebanyakan penelitian berusaha menghubungkan konflik peran dan ambiguitas peran dengan kepuasan kerja untuk mengukur tingkat stres dalam pekerjaan (Yousef, 2000; Harris, Artis, Walters, dan Licata 2006; Miles dan Petty, 1975; Hollon dan Chesser, 1976) dan gejala fisik serta kepuasan kerja pada intensi keluar (Egan, Yang, dan Bartlet, 2004; Bilal, Rehman, dan Raza, 2010).

Ada tiga model hubungan sebab-akibat diantara variabelvariabel stres peran, gejala fisik, kepuasan kerja dan intensi keluar. Model pertama yang dirumuskan oleh Locke (dalam Kemery et al., 1987), konflik peran dan ambiguitas peran berhubungan dengan 
kepuasan kerja yang kemudian berhubungan juga dengan gejala fisik dan pada akhirnya berhubungan dengan intensi keluar. Gejala fisik dimasukan dalam model ini karena berdasarkan teori Locke tentang kepuasan kerja dijelaskan pentingnya gejala fisik dalam pemahaman stres peran (konflik peran dan ambiguitas peran) yang berhubungan dengan pekerjaan. Model Locke ditunjukkan pada gambar 1.1.

Gambar 1.1

Model Locke

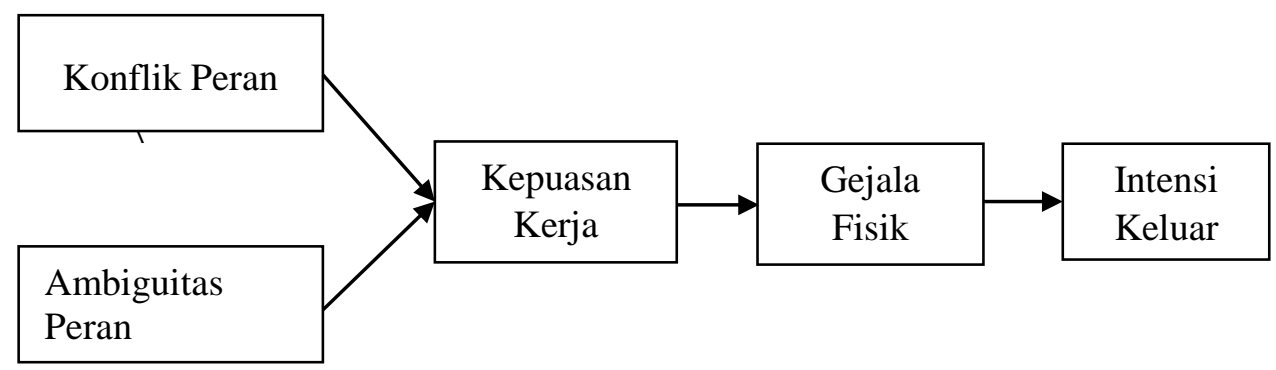

Sumber: Locke dalam Kemery et al., (1987)

Model kedua dirumuskan oleh Beehr dan Newman (1978), dengan mengadopsi model pertama, yang menjelaskan bahwa stres peran mungkin timbul dari beberapa segi, yaitu segi pribadi (karakteristik pribadi), segi lingkungan (aspek lingkungan individu), dan segi proses (orang $\mathrm{x}$ interaksi lingkungan). Karakteristik pribadi dapat terkait dengan segi proses, yang merupakan mekanisme psikologis dan fisiologis yang menggabungkan aspek lingkungan dan individu untuk menghubungkan orang dan lingkungan.

Menurut model Beehr dan Newman (1978), konsekuensi stres dapat diamati dalam tiga domain respon: fisiologis, emosional, dan perilaku. Akibat stres peran, dapat mengakibatkan peningkatan fisiologis (misalnya, resistensi kulit) dan/atau biokimia (misalnya, kolesterol) gejala stres, masalah emosional (misalnya, depresi), efek perilaku (misalnya, penggunaan dan 
penyalahgunaan narkoba), dan seterusnya. Stres peran (konflik peran dan ambiguitas peran) yang tinggi akan berdampak pada menurunnya kepuasan kerja dan gejala fisik (menurunnya kesehatan), dampak menurun ini akan berakibat pada intensi keluar. Model Beehr dan Newman ditunjukkan pada gambar 1.2.

Gambar 1.2

Model Beehr dan Newman

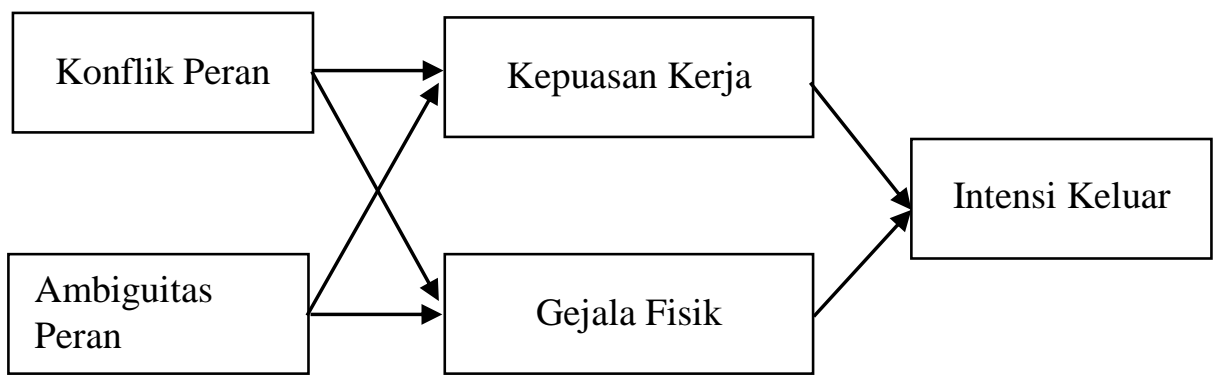

Sumber: Beehr dan Newman (1978)

Model ketiga, yang dirumuskan oleh Schuler (1982), hampir sama dengan model yang dirumuskan oleh Beehr dan Newman (1978). Namun, model ini memodifikasi model sebelumnya dengan memasukkan penyebab timbal balik, dengan asumsi bahwa variabel kepuasan kerja adalah salah satu akibat dari atau memiliki efek pada variabel lain dalam proses stres. Model ini juga mengakui bahwa variabel yang relevan mungkin saling terkait.

Kerangka kerja ini memprediksi bahwa, stres peran (konflik peran dan ambiguitas peran) berhubungan dengan kepuasan kerja dan gejala fisik (berinteraksi timbal balik). Jadi, jika pegawai tetap yang telah terkena stres peran, mendorong terjadinya peningkatan gejala fisik, dengan demikian tingkat ketidakpuasan dari pekerjaan juga meningkat. Aliran dua arah secara bersama-sama memiliki pengaruh langsung terhadap intensi keluar. Model Schuler ditunjukkan pada gambar 1.3. 
Gambar 1.3

Model Schuler

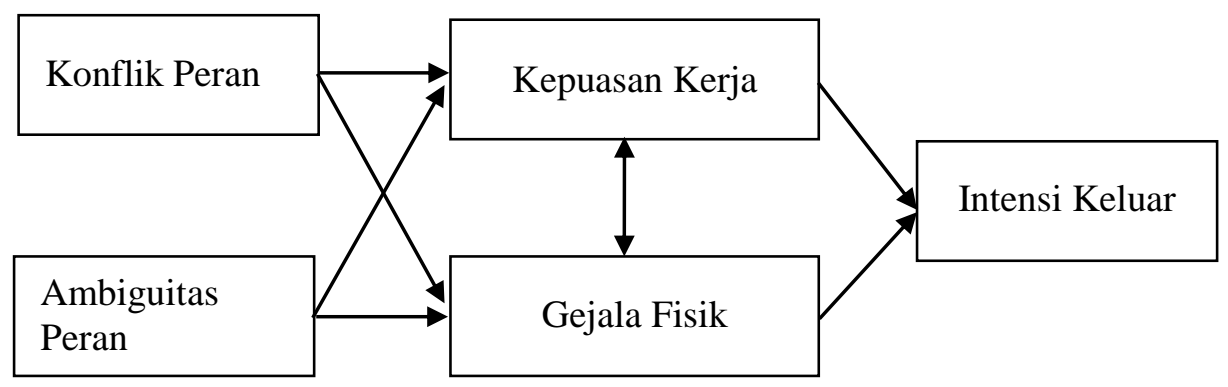

Sumber: Schuler (1982)

Penelitian yang menguji ketiga model di atas telah dilakukan oleh Kemery et al., (1987), yang hasilnya menunjukan model yang paling sesuai adalah model Beehr dan Newman (1978). Berdasarkan hasil pengujian dengan menggunakan structural equation model (SEM) menunjukan bahwa konflik peran dan ambiguitas peran berpengaruh terhadap kepuasan kerja dan gejala fisik yang selanjutnya berpengaruh pada intensi keluar.

Hasil penelitian di atas ternyata tidak konsisten dengan hasil penelitian yang lain, dengan pengujian model yang lebih sederhana (Kemery et al., 1987). Penelitian yang menghubungkan antara konflik peran dan ambiguitas peran dengan kepuasan kerja yang dilakukan oleh Yousef (2000), dan Harris et al., (2006) menunjukkan bahwa, konflik peran dan ambiguitas peran berhubungan negatif dengan kepuasan kerja. Sedangkan Miles dan Petty (1975), Hollon dan Chesser (1976), mengidentifikasikan bahwa konflik peran dan ambiguitas peran mempunyai hubungan yang positif dengan kepuasan kerja.

Penelitian yang menghubungkan antara kepuasan kerja dan intensi keluar ternyata berbeda antara penelitian yang satu dengan penelitian yang lain. Penelitian Egan et al., (2004) menemukan hubungan yang negatif signifikan antara kepuasan kerja dan intensi keluar, sedangkan penelitian yang dilakukan Bilal et al., (2010) menemukan hubungan yang positif antara kepuasan kerja dan intensi keluar. Berdasarkan temuan yang saling bertentangan 
ini, maka penulis memasukkan variabel pemoderasi afek positif. Alasan penulis memasukkan variabel afek positif karena berdasarkan Weitz (dalam Shaw, 1999) bahwa varibel afek positif perlu dipertimbangkan dalam kaitannya dengan hubungan antara kepuasan kerja dan intensi keluar.

Model yang digunakan dalam kajian ini adalah model Beehr dan Newman, (1978). Hal ini berdasarkan penelitian Kemery et al., (1987), yang menguji ketiga model tersebut (Locke dalam Kemery et al., 1987; Beehr dan Newman, 1978; dan Schuler, 1982), hasilnya menunjukkan model yang paling sesuai adalah Beehr dan Newman, (1978). Selain itu pada kajian ini penulis tidak menggunakan semua variabel, ada satu variabel yang dihilangkan yaitu gejala fisik. Alasan penulis tidak menggunakan variabel gejala fisik karena berdasarkan Kemery et al., (1987) bahwa untuk mengambil simpulan yang kuat dan akurat, khusus untuk variabel gejala fisik harus dilakukan dalam penelitian yang membutuhkan waktu yang lama atau dapat dilakukan dengan menggunakan desain longitudinal.

Kajian ini dilakukan di Kepolisian Maluku Utara. Pada saat ini Kepolisian Maluku Utara mengalami kekurangan sumber daya manusia maka yang berkualitas. Untuk mengatasi masalah ini, pimpinan Kepolisian Maluku Utara mengambil kebijakan bahwa seorang anggota polisi yang secara golongan belum memenuhi syarat tetapi karena kekurangan tersebut maka anggota polisi tersebut bisa menduduki jabatan yang belum sepantasnya secara golongan. Hal ini bisa mengakibatkan anggota polisi mengalami stres peran pekerjaan yang bisa berdampak pada menurunnya kepuasan kerja. Ketika seseorang anggota polisi mengalami penurunan kepuasan kerja maka akan meningkatkan tingginya intensi keluar anggota polisi tersebut. Kajian stres peran pada kepuasan kerja dan implikasinya pada intensi keluar dengan variabel afek positif sebagai pemoderasi di Indonesia pada konteks kepolisian masih sangat jarang ditemukan. 


\section{BAB II STRES KERJA}

Matteson dan Ivancevich (1979), mendefiniskikan stres sebagai respon adaptif yang disebabkan oleh tindakan, situasi, atau peristiwa yang memberikan tuntutan berlebihan kepada seseorang, baik secara psikologis maupun perilaku. Sementara itu, Schuler (1982) mendefinisikan stres merupakan suatu kondisi dinamis ketika individu dihadapkan pada kesempatan, hambatan, dan keinginan akan hasil yang penting dan ingin diperoleh, tetapi hasilnya tidak dapat dipastikan.

DeFrank dan Ivancevich (1998) menyatakan bahwa terdapat tiga faktor yang harus diperhatikan ketika mendefinisikan stres, yaitu 1) Stres mengacu pada reaksi terhadap situasi atau peristiwa, bukan situasi atau peristiwa itu sendiri, 2) Stres dapat memberikan tekanan dan respon yang berbeda-beda pada tiap individu, dan 3) stres dapat memberikan tekanan psikologis secara berlebihan (excessive psychology) dan tuntutan fisik (physical demands). Keadaan tersebut hanya terjadi pada situasi khusus.

\section{A. Pengertian Stres Kerja}

Charlton (1992) mengemukakan bahwa stres kerja dikonseptualisasikan dari beberapa persepsi, yaitu stres sebagai stimulus, stres sebagai respon, dan stres sebagai stimulusrespon. Stres sebagai stimulus merupakan pendekatan yang menitikberatkan pada lingkungan. Stres sebagai stimulus memandang stres sebagai suatu kekuatan yang menekankan pada individu untuk memberikan tanggapan terhadap stressor. Stres sebagai respon merupakan reaksi seseorang terhadap tekanan, baik secara psikologis (pola berpikir dan emosi), fisiologis (detak jantung dan keringat), maupun perilaku. Stres sebagai stimulus-respon merupakan konsekuensi dari interaksi antara stimulus lingkungan dengan respon individu. 
Beehr dan Newman (1978) mendefinisikan stres kerja sebagai suatu kondisi yang muncul akibat adanya ketidaksesuaian antara individu dengan pekerjaannya. Ketidaksesuaian tersebut berdampak pada perubahan dan penyimpangan fungsi normal individu tersebut.

\section{B. Faktor-faktor Penyebab Stres Kerja}

Kondisi-kondisi yang cenderung menyebabkan stres disebut stressors. Meskipun stres dapat diakibatkan oleh hanya satu stressors, biasanya karyawan mengalami stres karena kombinasi stressors. Secara umum menurut Parasuraman dan Alutto (1984), ada tiga sumber utama yang dapat menyebabkan timbulnya stres, yaitu:

1. Faktor Lingkungan

Keadaan lingkungan yang tidak menentu dapat menyebabkan pengaruh pembentukan struktur organisasi yang tidak sehat terhadap karyawan. Dalam faktor lingkungan terdapat tiga hal yang dapat menimbulkan stres bagi karyawan yaitu ekonomi, politik dan teknologi. Perubahan yang sangat cepat karena adanya penyesuaian terhadap ketiga hal tersebut membuat seseorang mengalami ancaman terkena stres. Misalnya, perubahan teknologi yang begitu cepat akan membuat keahlian seseorang tidak terpakai karena hampir semua pekerjaan dapat terselesaikan dengan cepat dan dalam waktu yang singkat.

2. Faktor Organisasi.

Dalam sebuah organisasi terdapat beberapa faktor yang dapat menimbulkan stres yaitu tuntutan peran, tuntutan interpersonal, struktur organisasi, dan pemimpin organisasi.

3. Faktor Individu

Pada dasarnya, faktor individu muncul dari dalam keluarga. Seperti masalah pribadi, ekonomi dan karakteristik pribadi dari keturunan. Hubungan pribadi antara keluarga yang kurang baik akan menimbulkan akibat pada pekerjaan yang akan dilakukan karena akibat tersebut 
dapat terbawa dalam pekerjaan seseorang. Sementara itu, masalah ekonomi bergantung pada bagaimana seseorang tersebut dapat menghasilkan penghasilan yang cukup bagi kebutuhan keluarga serta dapat menjalankan keuangan tersebut dengan seperlunya.

Karakteristik pribadi dari keturunan bagi tiap individu yang dapat menimbulkan stres terletak pada watak dasar alami yang dialami oleh seseorang tersebut. Untuk itu, gejala stres yang ditimbulkan pada tiap-tiap pekerjaan harus diatur dengan benar dalam kepribadian seseorang.

\section{Dampak Stres Kerja pada Perusahaan}

Schuller (dalam Schuler, 1982) mengidentifikasi beberapa perilaku negatif karyawan yang berpengaruh terhadap organisasi. Menurut kajian ini, stres yang dihadapi oleh karyawan berkorelasi dengan penurunan prestasi kerja, peningkatan ketidakhadiran kerja serta tendensi mengalami kecelakaan. Beberapa dampak negatif yang ditimbulkan oleh stres kerja adalah sebagai berikut:

1. Terjadinya kekacauan, hambatan baik dalam manajemen maupun operasional kerja;

2. Mengganggu kenormalan aktivitas kerja;

3. Menurunkan tingkat produktivitas; dan

4. Menurunkan pemasukan dan keuntungan perusahaan. Kerugian finansial yang dialami perusahaan karena tidak imbangnya antara produktivitasnya dengan biaya yang dikeluarkan untuk membayar gaji, tunjangan, dan fasilitas lainnya.

\section{Dampak Stres Kerja pada Karyawan}

Schuler (dalam Schuler, 1982) menjelaskan seorang karyawan yang mengalami stres mengalami tekanan darah tinggi, mudah marah, sulit membuat keputusan yang bersifat rutin, kehilangan selera makan, rentan terhadap kecelakaan dan sebagainya. Akibat dari stres dapat dikelompokkan dalam tiga kategori umum, yaitu: 
Pengaruh fisiologis, yang berupa perubahan dalam metabolisme, meningkatkan detak jantung, sesak nafas, menaikkan tekanan darah, menimbulkan sakit kepadala dan memicu terjadinya serangan jantung. Pengaruh psikologis, yang berupa ketegangan, kecemasan, kejengkelan, kejenuhan dan sikap menunda pekerjaan. Pengaruh perilaku, yaitu perubahan dalam tingkat produktivitas, mangkir dari pekerjaan, ingin keluar dari organisasi, selain itu juga perubahan dalam pola makan, pola merokok, konsumsi alkohol yang berlebihan, gelisah dan waktu tidur menjadi tidak teratur. 


\section{BAB III \\ KONFLIK DAN \\ AMBIGUITAS PERAN}

\section{A. Konflik Peran}

Peran adalah sekumpulan ekspektasi mengenai perilaku pada suatu posisi dalam struktur sosial (Khan et al dalam Rizzo et al., 1970). Ketika ekspektasi yang diharapkan tidak terpenuhi maka akan menimbulkan tekanan. Tekanan dalam pekerjaan disebabkan dua hal, yaitu konflik peran dan ambiguitas peran. Teori stres peran menyatakan bahwa ketika ekspektasi dari seorang individu tidak terpenuhi, maka individu tersebut akan mengalami stress, tidak puas dan menjadi tidak efektif dalam pekerjaan.

Konflik peran didefinisikan sebagai ketidaksesuaian atau ketidakcocokan persyaratan dalam suatu peran, yang diukur berdasarkan standar atau kondisi yang memengaruhi kinerja peran (Rizzo, House dan Lirtzman, 1970). Atau dapat dikatakan, konflik peran merupakan persepsi tentang ketidaksesuaian atau ketidakcocokan tuntutan-tuntutan yang diberikan dari tanggung jawab suatu peran (Abdel-Halim, 1981). Sedangkan menurut Van Sell et al., (dalam Schuler, 1982) konflik peran sebagai stressor potensial karena dapat menghalangi/mencegah seseorang untuk melakukan dengan baik semua peran, atau paling tidak dapat menyebabkan ketidakpastian tentang apa yang akan dikerjakan.

Rizzo et al., (1970) menjelaskan bahwa, ketidaksesuaian atau ketidakcocokan tersebut dapat menghasilkan konflik yang beragam, seperti:

1. Konflik antara nilai-nilai internal focal person, yang didefinisikan sebagai peran. Konflik ini merupakan konflik personal individu ketika mengisi suatu posisi tertentu. Misalnya, tugas yang diberikan terlalu mudah sehingga membosankan, dan atau pekerjaan yang dilakukan tidak sesuai dengan nilai-nilai pribadi. 
2. Konflik intrasender, yaitu konflik antar waktu, sumberdaya, atau kemampuan focal person, dengan perilaku peran yang ditentukan. Misalnya, tidak cukup waktu untuk melakukan pekerjaan yang diberikan, atau mendapatkan tugas yang tidak sesuai dengan kemampuannya.

3. Konflik antar peran, yaitu konflik antara beberapa peran karena focal person harus berbeda-beda, atau karena perilaku tersebut tidak saling bersesuaian, atau karena perubahanperubahan dalam berperilaku sesuai dengan situasi tertentu.

4. Ekspektasi dan tuntutan organisasional atau kebijakan yang saling bertentangan, permintaan yang bertentangan dari pihak lain, dan ketidaksesuaian standar evaluasi. Misalnya, pekerjaan yang diberikan tidak sesuai dengan kebijakan organisasi, atau menerima tugas yang saling bertentangan dari dua pihak.

Kendall, Murphy, O'Neil dan Bursnal (2000), konflik peran timbul jika seorang tenaga kerja mengalami adanya:

1. Pertentangan antara tugas-tugas yang harus ia lakukan dan antara tanggung jawab yang ia miliki.

2. Tugas-tugas yang harus ia lakukan yang menurut pandangannya bukan merupakan bagian dari pekerjaannya.

3. Tuntutan yang bertentangan dari atasan, rekan bawahannya atau orang lain yang dinilai penting bagi dirinya.

\section{B. Ambiguitas Peran}

Ambiguitas peran didefinisikan sebagai suatu keadaan yang mana suatu pekerjaan tersebut memiliki kekurangan dalam hal prediksi suatu respon terhadap perilaku lain dan kejelasan mengenai persyaratan perilaku yang diharapkan. Oleh karena itu, mencerminkan kepastian tentang tugas, wewenang, alokasi waktu, dan hubungan dengan orang lain, kejelasan atau adanya panduan, arahan, kebijakan, dan kemampuan untuk memprediksi sanksi sebagai hasil dari perilaku (Rizzo et al., 1970). 
Ambiguitas

peran

mungkin

juga

menghalangi/mencegah individu dalam hal rasa keberhasilan karena individu tersebut tidak jelas tentang apa yang telah dicapai (Van Sell et al., dalam Schuler, 1982).

Giebels, Ellen, dan Janssen (2005), mengemukakan faktor-faktor yang menimbulkan ambiguitas peran meliputi:

1. Ketidakjelasan dari saran-saran (tujuan-tujuan kerja),

2. Kesamaran tentang tanggung jawab,

3. Ketidakjelasan tentang prosedur kerja,

4. Kesamaran tentang apa yang diharapkan oleh orang lain,

5. Kurang adanya ketidakpastian tentang produktivitas kerja. 


\section{BAB IV \\ KEPUASAN KERJA}

Kepuasan kerja merupakan keadaan emosi yang senang atau emosi positif yang berasal dari penilaian pekerjaan atau pengalaman kerja seseorang (Brayfield dan Rothe, 1951). Porter, Lawler dan Hackman (dalam Cetin, 2006) menjelaskan bahwa kepuasan kerja adalah reaksi seseorang terhadap pekerjaan atau organisasi.

\section{A. Akibat Kepuasan Kerja}

Ada beberapa variabel yang menjelaskan adanya hubungan antara kepuasan kerja dan sejumlah variabel lain. Variabel-variabel tersebut antara lain sebagai berikut:

1. Motivasi

Meskipun sama-sama menjadi faktor pendorong perilaku, motivasi berbeda dengan komitmen organisasional. Komitmen biasanya terkait dengan keputusan penting yang memiliki periode yang panjang, misalnya komitmen untuk menikah, komitmen untuk meningkatkan kepuasan kerja karyawan, sedangkan motivasi terkait dengan dorongan untuk melakukan suatu pekerjaan dalam jangka pendek. Selain itu, motivasi memiliki pengertian yang lebih luas dibandingkan dengan komitmen (Meyer, Becker dan Vandenberghe, 2004). Sembilan studi meta-analisis yang melibatkan 1.739 karyawan menunjukkan hubungan yang positif antara motivasi dan kepuasan kerja, karena kepuasan kerja dengan supervisi juga berhubungan secara signifikan dengan motivasi, manajer disarankan untuk mempertimbangkan bagaimana perilaku mereka mempengaruhi tingkat kepuasan kerja mereka. Manajer dapat meningkatkan motivasi karyawan melalui berbagai upaya yang dapat meningkatkan tingkat kepuasan kerja mereka (Kinicki, McKee-Ryan, Schriesheim, \& Carson, 2002). 